\title{
KEBERADAAN OLAHRAGA RAKIT KREATIF DI KECAMATAN RAMBAH KABUPATEN ROKAN HULU
}

\author{
Joni Alpen \\ Universitas Islam Riau \\ alpenbungsu@yahoo.co.id
}

\begin{abstract}
ABSTRAK
Tujuan dari penelitian ini adalah untuk mengetahui bagaimana sejarah, sarana dan prasana, peraturan perlombaan serta bagaimana pelaksanaan perlombaan rakit kreatif. Penelitian ini di laksanakan di Kec. Rambah Kab. Rokan Hulu. Teknik pengumpulan adalah metode wawancara dengan jumlah sampel 52 orang yang terdiri dari lurah/kades, tokoh masyarakat, pembuat rakit, dan peserta. Hasil penelitian ini menunjukkan bahwa 52 sampel menyebutkan sejarah rakit ini datang dan berkembangnya dari masyarakat Rambah sendiri. Dengan berkembangnya zaman dari banyaknya teknologi yang hadir, maka tercetuslah ide dari bapak Auni M Noor selaku Wakil Bupati Kab. Rokan Hulu untuk membuat perlombaan rakit kreatif dengan tujuan mengingat kembali sejarah nenek moyang terdahulu. Sarana atau alat yang digunakan untuk membuat rakit adalah bambu. 45 sampel menyebutkan bambu yang digunakan adalah bambu pilihan. Orang Rambah menyebutnya (buluh poriang). Prasarana yang digunakan untuk perlombaan rakit kreatif ini adalah sungai Rokan yang ada di kec. Rambah Kab. Rokan Hulu dengan panjang etafe $80 \mathrm{~km}$. Dari 44 sampel menyebutkan perlombaan rakit kreatif ini mempunyai peraturan baku yang dibuat oleh Dinas Pariwisata Kab. Rokan Hulu. Pelaksanaan perlombaan ini dilaksanakan pada siang hari dengan memakan waktu 3 hari 3 malam dengan 3 etafe perbehentian.
\end{abstract}

Kata Kunci: Rakit Kreatif Kabupaten Rokan Hulu.

\section{PENDAHULUAN}

Permainan tradisional merupakan permainan yang berakar nilai kebudayaan setiap daerah, apabila dikelola secara professional merupakan suatu aset yang dapat membantu dalam peningkatan penghasilan pada daerah tersebut. Pembinaan dan pengembangan olahraga tidak hanya dilakukan oleh pemerintah pusat. Tetapi dapat dilakukan masyarakat mulai dari pelosok Desa, Kecamatan, Kabupaten hingga Propinsi baik itu olahraga modern maupun olahraga tradisional.

Hal ini sesuai dengan landasan keolahragaan Nasional dalam Undang-Undang Republik Indonesia No. 3 Tahun 2005 yang berbunyi: "Pembinaan dan pengembangan olahraga rekreasi yang bersifat tradisonal dilakukan dengan menggali, mengembangkan, melestarikan, dan memanfaatkan olahraga tradisional yang ada didalam masyarakat". Dari kutipan di atas dapat disimpulkan bahwa olahraga tradisional dapat diwujudkan dengan cara, digali unsur budayanya dan dikembangkan melalui tata peraturan permainannya, serta di lestarikan keberadaannya agar budaya tradisional sifatnya, dapat berkelanjutan buat tatapan generasi yang akan datang. 
Kegiatan perlombaan ini bermaksud melestarikan kebudayaan Rokan Hulu yang terinperasi dari kegiatan tradisional yang tergantung kepada Sungai Rokan sebagai sumber kehidupan Masyarakat. Menciptakan image dan ikon budaya yang dapat mewakili Kebudayaan Rokan Hulu. Menyalurkan kreativitas, sportifitas dan rasa cinta kepada alam Budaya Melayu Riau umumnya dan Kabupaten Rokan Hulu khususnya. Dengan kegiatan ini secara tidak sadar masyarakat tersebut akan tersentuh hati nalurinya untuk peduli dan cinta akan lingkungan sosial ekonomi masyarakat Rokan Hulu.

Begitu juga dalam pemberian nama pada rakit kreatif di percayai untuk menghidupkan nuansa lama yang sudah mulai dilupakan. Atau istilah pepatah adat Rambah dalam buku Sejarah Adat Istiadat Masyarakat Kepenuhan (2006:2) membangkitkan batang turundom (membangkitkan batang yang terendam). Dalam artian nilai budaya kita orang melayu yang terkenal dengan santun dan mempunyai tradisi yang mengandung nilai estetika yang tinggi, yang bertamaddun, dan bersandarkan pada Al-Quran dan hadist sehingga nilai budaya ini secara subtansial sangat relevan bila kembali di implementasikan sebagai acuan dalam menata kehidupan bersosial dan bermasyarakat. Perlombaan rakit disini adalah suatu perlombaan dengan menggunakan rakit yang mana diatas rakit dibuat rumah untuk berteduh yang dihiasi seindah mungkin. Rakit ini bergerak dengan mengikuti arus sungai yang dibantu dengan menggunakan dayung dan galah.

Perlombaan rakit kreatif yang ada di Kecamatan Rambah Kabupaten Rokan Hulu ini terdapat peraturan dan ketentuan yang telah ditentukan oleh panitia pelaksana dengan membentuk panitia terlebih dahulu yang akan mengurus berlangsungnya perlombaan rakit kreatif. Kemudian panitia tersebut menyebarkan undangan disetiap daerah yang ada di Kecamatan Rambah dua bulan sebelum perlombaan di laksanakan. Di undangan tersebut melampirkan tentang waktu, tempat peserta, ketentuaan perlombaan dan hadiah.

Dari sejarah singkat mengenai perkembangan olahraga rakit kreatif yang diperlombakan di Kecamatan Rambah memang cukup memberi arti tersendiri didalam sejarah kehidupan masyarakat setempat. Dengan adanya sejarah rakit kreatif ini masyarakat di Kecamatan Rambah Kabupaten Rokan Hulu berusaha agar nilai-nilai yang terkandung didalam perlombaan rakit kreatif ini tetap menjadi suatu modal dalam pengembangannya di Kecamatan Rambah khususnya dan Kabupaten Rokan Hulu umumnya. Hal seperti inilah yang mendorong hati penulis untuk melakukan penelitian lebih lanjut mengenai "Keberadaan Olahraga Rakit Kreatif Di Kecamatan Rambah Kabupaten Rokan Hulu".

\section{Teori}

\section{A. Sejarah Rakit}

Rakik atau dalam bahasa Indonesianya disebut rakit adalah alat transportasi sungai yang sangat tradisional dan sederhana yang digunakan oleh masyarakat sepanjang sungai rokan di masa lampau (berakhir tahun 1990-an) yang digunakan untuk sarana angkut masyarakat dalam membawa hasil bumi yang di jual keagen-agen terdekat bahkan sampai kerangau bagan siapi-api Kabupaten Rokan Hilir. Achmad Allatief Ardiwinata Suherman Marta Dinata (2006:3) dalam bukunya yang berjudul kumpulan permainan rakyat mengatakan bahwa: "Olahraga tradisional merupakan salah satu aspek yang perlu mendapatkan prioritas utama untuk di lindungi, di bina, di 
kembangkan, di perdayakan yang selanjutnya di wariskan”. Dari kutipan tersebut bisa diambil kesimpulan bahwa olahraga tradisional sangatlah penting untuk terus dikembangkan demi ketahanan budaya bangsa.

Pada prinsipnya perlombaan rakit kreatif ini adalah perlombaan tradisional yang sangat menarik untuk perlombakan. Selain itu, perlombaan rakit kreatif ini juga menggambarkan bahwa masyarakat memiliki kepedulian yang sangat tinggi dalam melestarikan budaya lama dalam kemasan kegiatan budaya, seni dan olahraga sebagai event tahunan yang dapat memberi inspirasi kepada masyarakat dalam penjabaran nilainilai budaya seperti kebenaran, keindahan, kemanusiaan, kebijakan dan kemurnian.

Sehingga pada tahun 2002 tercetuslah ide dari Bapak Auni M. Noor 72 Tahun waktu itu menjabat sebagai wakil bupati periode 2001-2006, membuat festival sungai rokan I yaitu terletak disungai Rokan kanan (sei batang lubuh) dengan nama kegiatannya "Lomba Rakit Kreatif". Yang mana perlombaan ini memakan waktu yang cukup lama yaitu 3 hari 3 malam dengan menempuh jarak lebih kurang $80 \mathrm{~km}$ dengan star dari pasir pengarayan sampai ke Kota Tengah dengan menelusuri sungai Rokan Kanan Ke hilir.

\section{B. Peraturan perlombaan Rakit}

Rakit kreatif dapat dipakai atau diperlombakan jika siap dikerjakan secara utuh oleh para pembuat rakit. Rakit yang diperlombakan terbuat dari buluh poriang (bambu poring) yaitu bambu yang ukurannyan panjang tidak tebal dan lurus. Bambu poring ini sangat jauh berbeda dengan bambu-bambu lainnya. Selain warnanya kuning bambu ini juga ringan. Begitu juga dalam proses pembuatannya. Didalam pengerjaannya tidak boleh menggunakan paku. Hanya menggunaka rotan. Ukuran rakit yang diperlombakan panjang 8 meter dan lebar 3 meter. Di dalam rakit tersebut di wajibkan membuat rumah atau tempat berlindung para peserta yang mana rumah tersebut berukuran Panjang 2,5 meter, lebar 1,70 meter dan tinggi $190 \mathrm{~cm}$.

Peralatan ataupun kelengkapan rakit yang diperlombakan adalah: 1) Setiap rakit wajib mempunyai dapur dan perlengkapan masak, 2) WC dan tempat sampah, 3) Tempat dayung 5 buah, 4) Galah 2 buah, 5) Dayung 5 buah, 6) Umbul-umbul atau bendera secukupnya, 7) Benen/pelampung 6 buah, 8) Perlengkapan tidur, 9) Tali sekurang-kurangnya 20 meter, 10) Kotak P3K dengan isinya (standar), 11) Bendera P3K (disediakan panitia) dipasang berdekatan dengan kotak P3K, 12) Lampu lentera dan senter, dibolehkan membawa genset (mesin listrik), 13) Pluit minimal satu, dan 14) Peralatan musik tradisional gendang bergong (tidak diwajibkan)

Ketentuan peserta perlombaan: 1) Peserta rakit kreatif terbuka untuk umum yang dapat mewakili daerahnya masing-masing baik itu utusan dari kecamatan, organisasi instansi pemerintah/swasta, pelajar/mahasiswa, 2) Peserta berusia 17 - 50 tahun yang dinyatakan sehat jasmani dan rohani oleh team medis, 3) Mendapat izin dari orang tua/wali bagi pelajar/mahasiswa, 4) Peserta yang ikut harus pandai berenang dan menyelam, 5) Peserta rakit dalam satu kelompok terdiri dari 6 (enam) orang peserta disebut dengan regu yang mana anggotanya tidak dapat diganti atau ditambah, 6) Dalam regu di pimpin oleh seorang tekong (mengendalikan rakit) biasanya tekong ini orang yang benar-benar paham dalam mengendalikan rakit. Di bantu oleh seoarng wakil tekong (tugasnya untuk meninjau selama perjalanan) dan 4 (empat) orang anggota rakit (arak) yang mana untuk mendayung depan 2 orang, dan dibelakang rumah 
rakit 2 orang, dan juru masak 1 orang, 7) Memiliki nomor undian yang disiapkan oleh panitia pelaksana, 8) Memberi nama pada rakit yang dikemudikan, 9) Setiap peserta rakit memiliki tanda peserta yang disediakan oleh panitia dan dikenakan selama acara berlangsung (merupakan bagian penilaian kategori kelengkapan rakit), 10) Dalam lomba peserta tidak boleh diganti, ditambah, atau diwakilkan dalam kegiatan lomba berlangsung, jika kedapatan anggota lebih dari enam orang didalam rakit dapat mengurangi nilai, 11) Peserta diansuransikan (ditanggung panitia), 12) Kebutuhan pokok dan kebutuhan lainnya dalam kelompok tidak ditanggung oleh panitia, 13). Akomodasi, konsumsi selama kegiatan tidak di sediakan panitia. Sumber Data : Dinas Pariwisata Kabupaten Rokan Hulu (Dalam Bukunya GBHB).

\section{Pelaksanaan Perlombaan Rakit Kreatif}

Perlombaan rakit kreatif yang ada di Kecamatan Rambah Kabupaten Rokan Hulu Provinsi Riau dilaksanakan oleh panitia pelaksana perlombaan bertempat di Rokan I yaitu (sungai batang lubuh.). Jalannya perlombaan rakit kreatif ini adalah mengikuti aliran sungai dari hulu tepatnya di Ibu Kota Pasir Pengarayan menuju ke hilir yang finish di Kecamatan Kepenuhan atau di Kota Tengah. Adapun susunan kepanitiaan perlombaan rakit kreatif yang ada di Kecamatan Rambah Kabupaten Rokan Hulu adalah Pelindung/penasehat, Ketua Umum, Sekretaris Umum, Bendahara Umum dan Seksi-Seksi lainnya.

\section{Sarana dan Prasarana}

Arena yang digunakan dalam perlombaan rakit kreatif yang dilaksanakan di Kecamatan Rambah Kabupaten Rokan Hulu adalah Sungai Rokan I (sei batang lubuh). Jarak dari star menuju ke finish lebih kurang $80 \mathrm{~km}$ Sumber Data:Dinas Pariwisata Kabupaten Rokan Hulu. Keberedaan Sungai Rokan I (sei batang lubuh) adalah : 1) Tinggi tebing rata-rata 5-7 meter, lebar lebih kurang 100 meter, banyak terdapat tunggul terutama tunggul re runtuhan tebing yang agak ketengah air setelah terjadi beberapa air dalam (banjir), 2) Sungai pada kedalaman 1/3 tebing sangat rawan untuk di lalui, dikarenakan sungai menyempit dan dangkal serta dihalangi oleh tunggak baru dan hamparan pasir, 3) Sungai pada kedalaman $1 / 2$ tebing tidak begitu ada kendala yang berarti dari lalu lintas sungai karena lebar sungai memungkinkan menghidari rintangan tunggul, namun harus berhati-hati dengan keadaan tunggul yang tidak nampak karena air keruh dan arus yang begitu kencang sehingga tidak dapat mengontrol rakit secara spontan, 4) Sungai pada keadaan ke dalaman bibir tebing di mungkinkan tidak dapat dilakukan kegiatan berakit karena rawan kecelakaan, 5) Keadaan rute antara star dan etape I dapat di lalui $1 / 2$ hari jika keadaan air $1 / 2-1 / 2$ tebing dan dapat lebih jika air dangkal, 6) Keadaan rute etape I dan etape II jarak yang cukup panjang dan melelahkan. Karena ditempuh dalam satu hari dan keadaan agak tenang tetapi banyak tikungan tajam dan daerah sempit.

\section{E. Jalannya Perlombaan}

Rakit dilepaskan satu persatu dengan selang waktu dua menit dengan rakit lainnya. Setelah sampai di Desa tersebut rakit tadi diparkirkan di pinggir sungai sesuai urutan yang pertama sampai di etape I untuk beristirahat. Ke esokan harinya rakit tadi dilepaskan sesuai dengan urutan yang pertama kali sampai di etape I dengan selang 
waktu pelepasan dua menit dengan rakit lainnya menuju etape II yaitu di desa tanjung alam tepatnya di Kecamatan Kepenuhan Hulu.

Sesampainya dietape II rakit tadi disusun kembali di pinggir sungai tersebut sesuai dengan urutan yang pertama kali sampai di etape II tersebut untuk beristirahat. Dan keesokan harinya lagi rakit tadi dilepaskan kembali sesuai dengan nomor urutan yang pertama kali sampai di etape II menuju finish yaitu didesa Kota Tengah tepatnya di Kecamatan Kepenuhan. Perjalanan lomba rakit kreatif ini di laksanakan pada siang hari dan beristirahat di etape yang ditetapkan oleh panitia pelaksana.

Biasanya disetiap perbehentian warga setempat mengadakan hiburan yang tujuannya adalah untuk pelepas rasa penat peserta perlombaan selama diperjalanan. Peserta perlombaan yang mengikuti perlombaan tersebut mempunyai dua ketentuan yang dibuat oleh panitia pelaksana perlombaan yaitu selama berakit dan selama didarat.

Selama Berakit: 1) Peserta rakit tidak dibenarkan membawa perhiasan dalam perjalanan. Jika hilang atau rusak diluar tanggung jawab panitia pelaksana, 2) Tidak boleh mengejek, berkelahi antar sesama grup rakit. 3) Dalam perjalanan tidak dibenarkan merusak lingkungan DAS, seperti meracun ikan, membuang sampah kesungai, menebang pohon pinggir sungai dan lain sebagainya yang sifatnya merusak. 4) Peserta rakit berlaku sopan didalam rakit dan sepanjang perjalanan. 5) Selama berakit tidak dibenarkan peserta turun dari rakit kecuali dalam keadaan memerlikan untuk turun ke air, 6) Selama dirakit diwajibkan memakai tanda peserta, 7) Tidak boleh merencanakan perusakan terhadap rakit lain, 8) Tidak boleh melakukan kegiatan yang dapat mengganggu kelancaran rakit lain, 9) Tidak dibenarkan membawa bahan peledak termasuk mercon atau kembang api, 10) Tidak boleh membawa narkoba, miras, senjata api serta senapan angin apalagi memakai, meminum dan menggunakan barang tersebut, 11) Peserta rakit dalam keadaan darurat memberi tahu tim sar atau keamanan, kesehatan atau peserta rakit lain dengan menggunakan pesan berantai, 12) Peserta yang melakukan tindakan kriminal atau yang bertentangan dengan hukum dan terbukti akan diserahkan kepada pihak berwajib dan diproses secara hokum pula, 13) Berpakaian sopan dalam berakit, 14) Dapat menggunakan alat musik selama perjalanan dengan musik yang sopan dan ramah lingkungan.

Selama Didarat: 1) Setiap merapat peserta mengatur rakit dengan tertib, aman hingga tidak mengganggu dan merusak rakit lain, 2) Setelah merapat dan mengikat rakit, peserta diwajibkan melapor keposko kesehatan untuk memeriksa kesehatan, 3) Tidak boleh mengganggu rakit lain, 4) Berlaku sopan didaerah yang di singgahi, 5) Tidak boleh mengganggu penduduk serta segala sesuatau milik masyarakat didaerah yang disinggahi, 6) Tidak boleh mencuri atau merusak milik rakit lain ataupun milik penduduk, 7) Tidak boleh membawa siapapun kerakit untuk menginap baik pria maupun wanita, 8) Tidak dibenarkan membakar rakit sebelum dan sesudah finish, jika tertangkap tangan grup mereka dikenakan sanksi yaitu tidak diperbolehkan ikut serta pada tahun yang akan datang, 9) Jika ingin berpergian meninggalkan rakit atau melakukan kegiatan hobi memancing dan lain sebagainya harus melaporkan terlebih dahulu dengan tekong (ketua rakit) jika berpergian jauh dari lokasi harus melaporkan kepanitia (tim sar).

\section{F. Faktor Penyebab Tidak Berkembangnya}

Menurut informasi yang di dapat dari tokoh masyarakat yaitu bapak yusrisam 35 tahun, ada beberapa faktor penyebab tidak terlaksananya lagi perlombaan ini yaitu: 
a) Faktor dana yang tidak mendukung untuk mengadakan perlombaan ini karena besarnya anggaran yang akan dikeluarkan untuk mengadakan perlombaan rakit kreatif ini, b) Partisipasi masyarakat sudah mulai berkurang terhadap perlombaan ini, c) Banyaknya melibatkan tenaga atau panitia pelaksana, Alasan lain juga diutarakan takut terancam habisnya bambu dan terjadinya erosi dikarenakan bambu-bambu yang digunakan untuk perlomban ini mayoritas tumbuh dipinggir sungai. Banyaknya kalangan masyarakat tidak lagi peduli tentang keasrian sungai rokan I (sei batang lubuh).

Padahal kalau event tahunan ini terus diadakan, akan menciptakan sumber daya manusia yang meningkat. Mengapa tidak? secara tidak langsung kita telah membantu masyarakat untuk mau merawat bambu yang ada. Karena di dalam proses pembuatan rakit kreatif semua bambu dibeli dengan harga Rp.5000/batang dan jumlah dalam pembuatan rakit kreatif memakan bambu sebanyak 60-80 batang dalam satu rakit. Sedangkan peserta perlombaan tiap tahunnya meningkat. Selain itu bambu bisa juga dibuat industri kerajinan tangan dari Kabupaten Rokan Hulu seperti tikar, keranjang dan lain sebagainya yang bisa dimanfaatkan dari bambu tersebut. Karena didalam perlombaan rakit kreatif, sesampainya di finish semua peserta rakit tidak membawa pulang lagi rakitnya.

Banyak sebenarnya keuntungan yang didapat dalam perlombaan rakit tersebut, selain bisa menghibur Rakyat, ekonomi Masyarakat meningkat, dan juga mempunyai hasil produksi kerajinan tangan yang memiliki harga jual yang bisa di banggakan di Propinsi. Tapi itulah realita yang ada di Kabupaten Rokan Hulu sekarang ini. Amat di sayangkan acara tahunan ini dihilangkan, selain menghilangkan tradisi, juga menghilangkan budaya yang ada. Hal ini sesuai dengan pendapat Mahyudin Sudarno (2003:156) Didalam buku Alam Melayu; sejumlah gagasan menjemput keagungan. Beliau berpendapat bahwa "orang melayu hendaklah menyadari pentingnya mengembangkan budaya berpikir mereka, karena maju mundurnya seseorang, maju mundurnya suatu kaum, bahkan suatu etnis, bergantung kepada cara mereka berpikir, yaitu cara mereka menggunakan akalnya untuk menaklukan alam, mengelola kekayaan alam yang diberikan Allah kepada manusia. Apabila cara berpikir mereka tidak berkembang, maka betapapun kaya sumber daya alam dikaruniakan Allah kepada manusia, ia akan sia-sia".

Dari kutipan di atas bisa disimpulkan bahwa cara berpikir seseorang akan menentukan kemampuannya dalam mengelola akalnya untuk mencapai kemajuan. Orang melayu bisa menjadi sama majunya dengan etnis-etnis lain didunia. Jika mereka mau mengembangkan budaya berpikir mereka, seperti halnya etnis-etnis lain yang sudah maju. Dan mereka bisa melakukannya kalau mereka mau.

\section{METODE PENELITIAN}

Metode yang digunakan dalam penelitian ini adalah metode induktif, guna untuk mendiskripsikan perkembangan permainan tradisional rakit kreatif di Kecamatan Rambah Kabupaten Rokan Hulu, sedangkan tekhnik yang digunakan dalam penelitian ini adalah wawancara dilakukan dengan cara mengajukan pertanyaan-pertanyaan kepada responden. Wawancara ini berstruktur dan mengajukan pertanyaan sekitar masalah penelitian.

Selain itu tekhnik yang digunakan adalah studi kepustakaan. Tekhnik ini digunakan untuk mencari teori-teori pendukung yang toleran dengan masalah 
penelitian. Analisa dilaksanakan dengan melakukan telaah terhadap fenomena atau peristiwa secara keseluruhan, maupun terhadap bagian-bagian yang membentuk fenomena-fenomena tersebut serta hubungan terkait. Analisa data dilakukan dengan menguji kesesuaian antara data yang satu dengan data yang lain.

Selanjutnya sujana (2006) mengatakan analisis data kualitatif bertolak dari fakta atau informasi yang didapat di lapangan. Fakta atau informasi tersebut kemudian diseleksi dan di kembangkan menjadi pertanyaan-pertanyaan yang penuh dengan makna. Dengan demikian, Data dan informasi yang dikumpulkan yang berhubungan dengan pertanyaan penelitian akan dianalisa berupa pengelompokan dan pengkatagorikan dalam aspek-aspek yang telah ditentukan, hasil pengelompokan tersebut dihubungkan dengan data yang lainnya untuk mendapatkan suatu kebenaran.

Populasi penelitian ini adalah seluruh masyarakat Rambah yang terdiri dari 13 desa dan kelurahan yang ada di Rambah yang meliputi adanya Lurah, Tokoh Masyarakat, tukang rakit kreatif dan peserta yang mengikuti rakit kreatif yang berjumlah 140 orang. Sasaran penulis adalah seluruh rakit kreatif yang ada disetiap kelurahan atau desa yang ada di Kecamatan Rambah, Berhubungan peserta rakit kreatif di Kecamatan Rambah Kabupaten Rokan Hulu terlalu banyak dan luasnya Kecamatan Rambah, maka penulis melakukan sampel wilayah. Penulis mengambil 1 (satu) Tukang pembuat rakit dan 1 (satu) Peserta dari setiap kelurahan atau desa yang terdapat dalam populasi. Pengambilan sampel $37 \%$ dari populasi 140 dijadikan sebagai sampel yaitu sebanyak 52 orang.

\section{HASIL DAN PEMBAHASAN}

\section{A. Sejarah Perlombaan Rakit Kreatif Di Kecamatan Rambah Kabupaten Rokan Hulu.}

Berdasarkan hasil wawancara di lapangan dengan 52 orang sampel yaitu 13 orang Kepala Desa, 13 orang tokoh Masyarakat, 13 orang Tukang Rakit Kreatif, dan 13 orang peserta bahwa, sejarah rakit mulai dikenal oleh masyarakat Rambah jauh sebelum Kemerdekaan Republik Indonesia yaitu di masa nenek moyang terdahulu. Rakit datang dan berkembang dari Masyarakat Rambah sendiri. Pada tahun 2002 rakit kreatif ini mulai diperlombakan dengan jumlah peserta yang mengikuti 42 peserta. Yang mengikuti perlombaan tersebut adalah kaum laki-laki saja yang sehat jasmani dan rohani dan pandai berenang.

\section{B. Sarana Dan Prasarana Rakit Kreatif Di Kecamatan Rambah Kabupaten Rokan Hulu.}

Di dalam proses pembuatan rakit kreatif semua bambu bisa dijadikan rakit kreatif. Tapi kebanyakan peserta menggunakan bambu poring. Jumlah yang dibutuhhkan berkisar antara 50-100 batang bambu dan bambu tersebut kebanyakan dibeli. Proses pembuatan rakit kreatif tersebut bambu yang digunakan terlebih dahulu dikeringkan supaya daya apung bambu tersebut semakin kuat dan memakan waktu 1 bulan dalam proses penyelesaiannya. Bahan baku yang digunakan sangat mudah diperoleh.

Hal yang unik dijumpai adalah didalam pembuatan rakit tidak ada satupun rakit yang menggunakan paku hanya menggunakan rotan dan akar kayu yang bisa dijadikan untuk pengikat. Di dalam proses pembuatan rakit kreatif peserta yang mengikuti 
perlombaan tersebut menyelesaikan rakitnya dengan cara bekerja sama atau berkelompok dan tidak menggunakan acara ritual khusus dan bacaan mantra-mantra.

Rakit kreatif dijalankan menggunakan dayung dan dibantu dengan galah. Galah yang dimaksud di sini adalah kayu panjang yang kuat untuk mengendalikan jalannya rakit. Setiap peserta yang mengikuti perlombaan ini wajib membawa alat keselamatan seperti ban atau benen. Dan arena yang digunakan sangat memadai untuk perlombaan rakit kreatif ini.

\section{Peraturan Perlombaan Rakit Kretif}

Berbicara tentang peraturan perlombaan rakit kreatif di Kecamatan Rambah Kabupaten Rokan Hulu bahwa sudah ada peraturan dan ketentuan yang dibuat sudah di tetapkan oleh panitia pelaksana bekerja sama dengan Dinas Pariwisata. Setiap tahunnya tentu ada perubahan-perubahan peraturan, hal tersebut terlihat dari ukuran rakit maupun jumlah peserta yang mengikuti. Penyempurnaan peraturan tentu perlu dilakukan demi sempurnanya perlombaan rakit kreatif ini.

\section{Pelaksanaan Perlombaan Rakit Kreatif}

Pelaksanaan perlombaan rakit kreatif di Kecamatan Rambah Kabupaten Rokan Hulu tahun 2002-2004 sangat baik. Di lihat dari jumlah peserta yang mengikuti perlombaan ini setiap tahunnya mengalami peningkatan. Animo dan antusias penonton sangat mengingkat. Jalannya perlombaan ini pada siang hari yang memakan waktu yang cukup lama yaitu 3 hari 3 malam dengan 3 etave berhenti. Di setiap etave atau perbehentian masyarakat setempan mengadakan acara hiburan seperti permainan tradisional dan juga musik yang tujuannya untuk pelepas rasa penat selama perjalanan.

\section{KESIMPULAN}

Berdasarkan analisis data dan data tentang keberadaan olahraga rakit kreatif di Kecamatan Rambah Kabupaten Rokan Hulu yang merupakan topik dari skripsi ini, maka dapat di tarik kesimpulan sebagai berikut :

1. Sejarah rakit masuk dan dikenal di Masyarakat Rambah sudah dari Nenek Moyang terdahulu dan perlombaan rakit kreatif yang ada di Kecamatan Rambah Kabupaten Rokan Hulu Provinsi Riau baru dilaksanakan di masa Pemerintahan Bapak Bupati Ramlan Zaz SH.MH yang menjabat sebagai bupati. Perlombaan ini hanya berjalan 3 (tiga) tahun berturut-turut yaitu pada tahun 2002, 2003, dan 2004.

2. Sarana dan prasarana yang digunakan sangat memadai, baik bahan bakunya yang mudah diperoleh maupun arena yang digunakan sangat memadai.

3. Sudah adanya peraturan yang ditetapkan oleh panitia pelaksana yang bekerja sama dengan Dinas Pariwisata Kabupaten Rokan Hulu.

4. Dan pelaksanaan perlombaan rakit kreatif di Kecamatan Rambah Kabupaten Rokan Hulu Provinsi Riau di masa existensinya berjalan dengan lancar dan sangat berkembang. Hal tersebut dilihat dari jumlah peserta yang mengikuti dan animo masyarakat sangat mendukung. 


\section{DAFTAR PUSTAKA}

Arikunto, Suharsimi. (2006). prosedur penelitian suatu pendekatan praktik. Cetakan ketigabelas. Jakarta: PT. Rineka Cipta.

Ardiwinata, Achmad Allatief, dkk. (2006). kumpulan permainan rakyat olahraga tradisional. Cetakan pertama. Jakarta: Cerdas Jaya.

Fahmi, Khairul dan Hamka Ismail. (2006). sejarah dan adat istiadat masyarakat kepenuhan. Cetakan pertama Yogyakarta, growok, Belukar Komplek Polri.

Festival Sungai Rokan III Lomba Rakit Kreatif. (2004). Garis Besar Haluan Borakik. Kabupaten Rokan Hulu.

Habibi, Muhammad. (2008). Perkembangan Permainan Tradisional Jong Layar Di Kecamatan Meral Kabupaten Karimun. Pekanbaru.

Rahman, Elmustian, dkk. (2003). Alam Melayu Jumlah Gagasan Menjemput Keagungan. Pekanbaru: Unri Press.

Sujono, Anas. (2006). pengantar statistik pendidikan. Jakarta: PT. Rajagrafindo Persada.

UU Republik Indonesia. (2005). Landasan Keolahragaan Nasional. 